\title{
THE TOOTH SIZE IN THE END OF THE ESTONIAN IRON AGE
}

\author{
Jana Limbo \\ Tallinn University, Institute of History, \\ Department of Archaeobiology and Ancient Technology, Estonia
}

\begin{abstract}
Mesiodistal (MD) and buccolingual (BL) crown diameters of all observable permanent teeth were measured in four skeleton series from the Iron End Estonia, total of 254 individuals. Teeth sizes in the End of the Estonian Iron Age were typical of Northern Caucasoids who are mesodontic. All the teeth in the observed group were larger than in the historical skulls from Southern Lithuania and smaller than in historical skulls from Northern Finland. As for adult individuals, the sex was determined and teeth measures were registered separately in men and women. Differences between men and women were calculated. All the men had teeth bigger than women and although these differences were moderate, most of them were statistically significant. Most dimorphic teeth were upper canines (difference between male and female BL $8.3 \%, \mathrm{VL}-6.4 \%$ ) and the discriminant analysis based on upper canine tooth measures enabled correctly classify $88.2 \%$ of women and $73.6 \%$ of men. Least dimorphic were upper and lower incisors, which did not differ between men and women.
\end{abstract}

Key words: the End of the Estonian Iron Age, tooth size, odontometry, sex differences.

\section{INTRODUCTION}

Teeth size (length and width) are most often registered anthropological measures [15]. Teeth are simple to measure with high reliability and data are easy to process because it is distinctive to each population that both men's and women's teeth dimensions are subject to normal 
distribution, as it is also common to all adult anatomical measures within one certain population [14].

Archaeological bone collections usually differ from this ideal population with normal distribution, because of the subjects' small number and uncertain derivation.

Teeth have a special meaning in archaeology due to the reason of them being the strongest bone structures left after death and decay. It is also important that once fully formed, teeth's size and form will not change during the lifetime and therefore it is possible to measure and compare all the fully formed teeth crowns. It gives a chance to study teeth morphology in the groups where the age of individuals varies.

It is common in archaeology to use teeth measures to determine teeth size differences between men and women to establish the sex of individuals $[5,17,18]$. The determination of sex on the basis of teeth measures is also used in today's forensic medicine [4], it is possible due to the fact that teeth measures are larger for men than women in all human populations $[4,5,12,14,15,18]$. Also in archaeological bone collections bilateral asymmetry of dental dimensions is measured to estimate the stress level in different populations [14, 15, 16, 22].

Teeth sizes are also measured to compare differences between populations. In some cases it is possible to identify differences between the populations so precisely that it enables to determine belonging of single individuals to different human populations [19]. However, it is usually impossible to distinguish close human populations based on tooth size, because although tooth measures are population specific and under strict genetical control [9], the final size of teeth is determined by many genes and in addition to heritability the environment is also important in the formation of final size of a tooth $[9,14,15]$. The tooth size reflects a complex interaction between a variety of genetic and environmental factors during the morphogenesis [16] and has a continuous range of variations among individuals and between populations. Still, as separate human populations have different teeth sizes and no matter if the cause to that is the environment or genes, it will enable to use odontometry to differentiate human populations by teeth metrical features $[6,13,15]$.

Teeth measures have also been changing throughout the time in addition to genetic and environmental affects. It is mostly described by 
the teeth size reduction, for example, as it is clearly been observed in Europe since Upper Paleolithic to the modern times [3, 11].

Although it is determined that teeth features are different comparing separate populations, there is also possible the inner population differentiation of groups by measuring the teeth. For groups being men and women. The teeth size is bigger for men in all the population, only the extent of difference varies.

The aim of the current work is to describe the teeth measures of skeletal series from the End of the Iron Age and compare it to neighbouring historical skeletal series. The aim is also to find differences in teeth sizes between men and women, the extent of these differences, and if it is possible to distinguish men and women based on these differences.

\section{MATERIAL AND METHODS}

For all the studied permanent teeth, the maximal length or buccolingual (BL) diameter and maximal width or mesiodistal (MD) diameter was measured in four skeletal series (Pada, Jõuga, Karja, Viira) from the End of the Estonian Iron Age $\left(11^{\text {th }}-14^{\text {th }} \mathrm{cc}\right)[14,25]$.

It was possible to measure the permanent teeth of 253 subjects. Teeth were measured with a sliding calliper with the accuracy of $0.1 \mathrm{~mm}$. The teeth with fractured or extremely worn crowns, strong caries or dental calculus, were excluded from the study. Medium sizes of antimeres were used, and only then the individual had one tooth present from two antimeres, the remaining tooth measures were used.

The sex of adult subjects, 192 all together, was determined using conventional skeletal-based methods $[7,23]$. Teeth sizes were separately registered for 104 men and for 88 women. The percentage of the size difference of men and women was registered.

Both the robustness index (tooth area $\left.\mathrm{mm}^{2}\right)-\mathrm{BL}(\mathrm{mm}) \times \mathrm{MD}(\mathrm{mm})$ and crown module $\mathrm{m}_{\text {cor }}=\left(\mathrm{BL}_{\mathrm{cor}}+\mathrm{MD}_{\text {cor }}\right) / 2[14,25]$ were used to describe the teeth overall size. The crown index $\mathrm{I}_{\text {cor }}=\left(\mathrm{BL}_{\mathrm{cor}} / \mathrm{MD}_{\mathrm{cor}}\right) \mathrm{x}$ $100[14,25]$ was used to describe the shape of molars. For comparison skeletal series from Lithuania, Estonia and Finland were used [2, 5, 10, $21,24]$.

Statistically significant differences between men and women were found using the Student's t-test. Differences with $\mathrm{P}<0.05$ were 
considered statistically significant. The discriminant analysis was used to find out if differences in the tooth size can be used for sex determination. The statistical package SPSS was used for data processing.

\section{RESULTS}

The descriptive statistics of crown diameters are reported in Table 1. Both mesiodistal and buccolingual measures in maxilla and mandible correspond to the formula $\mathrm{M}^{1}>\mathrm{M}^{2}>\mathrm{M}^{3}$. The molars crown module, reflecting the size of molars crown, was on upper molars $m_{\text {cor }} \mathrm{M}^{(1-3)}=$ 10.35 .

The index showing molars features was as follows:

$$
\text { upper molars } \mathrm{I}_{\text {cor }} \mathrm{M}^{1}=110, \mathrm{I}_{\text {cor }} \mathrm{M}^{2}=117, \mathrm{I}_{\text {cor }} \mathrm{M}^{3}=119
$$

lower molars $\mathrm{I}_{\text {cor }} \mathrm{M}_{1}=92,7, \mathrm{I}_{\text {cor }} \mathrm{M}_{2}=94,3, \mathrm{I}_{\text {cor }} \mathrm{M}_{3}=92.3$

All the teeth sizes there were larger for men than women with the exception of the width of upper incisors and both the width and length of lower incisors. The difference for all the teeth was bigger on the upper jaw. Although the percentage of difference is small, it is still statistically significant. The biggest difference can be seen comparing the width of upper canines of men and women (BL) $-8.3 \%$, t-test $\mathrm{p}<0.01$. By using the discriminant analysis with these teeth it was possible to correctly identify $73.6 \%$ men and $88.2 \%$ women (Table 2 ).

\section{DISCUSSION}

The general pattern in teeth sizes, distinctive to all human groups, are also noted in the skeletal series from the Estonian Iron Age. BL measures are growing distal direction for the upper teeth and from MD diameters of the upper jaw it is the highest for the molars and the lowest for premolars. The lower jaw has similar BL and MD sizes for teeth [14].

Distinctive to Europeans are the crown indexes for lower and upper molars [25]. 
Table 1. Mesiodistal (MD) and buccolingual (BL) diameters of teeth in the total sample of the End of the Estonian Iron Age, and in men and women

\begin{tabular}{|c|c|c|c|c|c|c|c|c|c|c|c|c|}
\hline \multirow{2}{*}{\multicolumn{2}{|c|}{ Upper jaw }} & \multicolumn{3}{|c|}{ Total } & \multicolumn{3}{|c|}{ Male } & \multicolumn{3}{|c|}{ Female } & \multicolumn{2}{|c|}{$\begin{array}{c}\text { Diff. Betw. } \\
\text { M \& W }\end{array}$} \\
\hline & & $\mathbf{N}$ & $\mathrm{X}$ & Std & $\mathbf{N}$ & $\mathbf{X}$ & Std & $\mathbf{N}$ & $\mathbf{X}$ & Std & $\%$ & $\mathrm{p}$ \\
\hline \multirow[t]{2}{*}{ I1 } & BL & 108 & 6.9 & 0.50 & 39 & 6.9 & 0.45 & 32 & 6.9 & 0.60 & 0 & \\
\hline & MD & 85 & 8.4 & 0.59 & 32 & 8.5 & 0.08 & 23 & 8.2 & 0.14 & 3.5 & \\
\hline \multirow[t]{2}{*}{ I2 } & BL & 108 & 6.1 & 0.35 & 41 & 6.1 & 0.30 & 35 & 6.1 & 0.36 & 0 & \\
\hline & MD & 86 & 6.5 & 0.49 & 33 & 6.5 & 0.45 & 25 & 6.4 & 0.55 & 1.5 & \\
\hline \multirow[t]{2}{*}{$\mathrm{C}$} & BL & 126 & 8.2 & 0.56 & 61 & 8.5 & 0.47 & 41 & 7.8 & 0.45 & 8.3 & $* *$ \\
\hline & MD & 112 & 7.6 & 0.45 & 53 & 7.8 & 0.42 & 38 & 7.3 & 0.35 & 6.4 & $* *$ \\
\hline \multirow[t]{2}{*}{ P1 } & BL & 107 & 8.9 & 0.56 & 52 & 9.0 & 0.48 & 36 & 8.7 & 0.62 & 3.3 & * \\
\hline & MD & 109 & 6.7 & 0.38 & 54 & 6.8 & 0.35 & 36 & 6.5 & 0.38 & 4.4 & $*$ \\
\hline \multirow[t]{2}{*}{ P2 } & BL & 103 & 9.0 & 0.61 & 48 & 9.2 & 0.58 & 37 & 8.9 & 0.52 & 3.3 & * \\
\hline & MD & 102 & 6.4 & 0.41 & 49 & 6.5 & 0.39 & 36 & 6.3 & 0.38 & 3.1 & \\
\hline \multirow[t]{2}{*}{ M1 } & BL & 135 & 11.3 & 0.54 & 46 & 11.5 & 0.49 & 34 & 11.0 & 0.52 & 4.3 & $* *$ \\
\hline & MD & 135 & 10.3 & 0.58 & 43 & 10.4 & 0.58 & 37 & 9.9 & 0.55 & 4.8 & $* *$ \\
\hline \multirow[t]{2}{*}{ M2 } & BL & 142 & 11.2 & 0.63 & 56 & 11.4 & 0.56 & 50 & 10.9 & 0.49 & 4.4 & $* *$ \\
\hline & MD & 145 & 9.6 & 0.57 & 58 & 9.7 & 0.53 & 52 & 9.4 & 0.48 & 3.1 & $* *$ \\
\hline \multirow[t]{2}{*}{ M3 } & BL & 90 & 10.7 & 0.80 & 46 & 11.0 & 0.66 & 38 & 10.3 & 0.85 & 6.3 & $* *$ \\
\hline & MD & 88 & 9.0 & 0.65 & 46 & 9.1 & 0.64 & 38 & 8.8 & 0.65 & 3.3 & $*$ \\
\hline \multicolumn{13}{|c|}{ Lower jaw } \\
\hline \multirow[t]{2}{*}{ I1 } & BL & 103 & 5.7 & 0.41 & 34 & 5.8 & 0.06 & 28 & 5.7 & 0.10 & 0 & \\
\hline & MD & 66 & 5.3 & 0.36 & 16 & 5.3 & 0.44 & 11 & 5.2 & 0.38 & 1.9 & \\
\hline \multirow[t]{2}{*}{ I2 } & BL & 107 & 6.0 & 0.32 & 41 & 6.1 & 0.35 & 30 & 6.0 & 0.29 & 0 & \\
\hline & MD & 90 & 5.8 & 0.38 & 31 & 5.8 & 0.35 & 24 & 5.8 & 0.42 & 0 & \\
\hline \multirow[t]{2}{*}{ C } & BL & 121 & 7.6 & 0.55 & 59 & 7.8 & 0.43 & 35 & 7.2 & 0.48 & 7.7 & $* *$ \\
\hline & MD & 112 & 6.8 & 0.47 & 52 & 6.9 & 0.5 & 33 & 6.4 & 0.5 & 7.2 & $* *$ \\
\hline \multirow[t]{2}{*}{ P1 } & BL & 111 & 7.6 & 0.55 & 54 & 7.7 & 0.48 & 38 & 7.5 & 0.52 & 2.6 & $*$ \\
\hline & MD & 115 & 6.7 & 0.39 & 56 & 6.8 & 0.38 & 40 & 6.6 & 0.4 & 2.9 & $*$ \\
\hline \multirow[t]{2}{*}{$\mathbf{P 2}$} & BL & 104 & 8.0 & 0.55 & 53 & 8.1 & 0.77 & 38 & 8.0 & 0.87 & 1.2 & \\
\hline & MD & 106 & 6.7 & 0.49 & 54 & 6.8 & 0.6 & 38 & 6.6 & 0.9 & 2.9 & \\
\hline \multirow[t]{2}{*}{ M1 } & BL & 117 & 10.2 & 0.53 & 41 & 10.3 & 0.49 & 24 & 10 & 0.56 & 2.9 & $*$ \\
\hline & MD & 114 & 11.0 & 0.59 & 39 & 11.0 & 0.65 & 22 & 10.6 & 0.49 & 3.6 & $*$ \\
\hline \multirow[t]{2}{*}{ M2 } & BL & 102 & 9.9 & 0.51 & 49 & 10.1 & 0.48 & 32 & 9.6 & 0.39 & 4.9 & $* *$ \\
\hline & MD & 103 & 10.5 & 0.59 & 47 & 10.6 & 0.55 & 47 & 10.6 & 0.55 & 2.7 & $*$ \\
\hline \multirow[t]{2}{*}{ M3 } & BL & 74 & 9.6 & 0.65 & 44 & 9.8 & 0.58 & 28 & 9.2 & 0.46 & 6.1 & $* *$ \\
\hline & MD & 78 & 10.4 & 0.75 & 48 & 10.6 & 0.64 & 28 & 10.1 & 0.84 & 4.7 & * \\
\hline
\end{tabular}

$\mathrm{MD}$ - Mesiodistal and $\mathrm{BL}$ - buccolingual diameters (in $\mathrm{mm}$ ), $\mathrm{M}$ - the mean values and STD - standard devations.

Differences between men and women - T-test, value of $p$ (statistical significance of differences) $*-p \leq 0.05 ; * *-p \leq 0.01$ 
Table 2. The summary of statistics of canonical discriminant functions for tooth size differences between male and female. The most dimorphic teeth $\mathrm{BL}$ and MD diameters

\begin{tabular}{|c|c|c|c|c|c|}
\hline Tooth & Sex & $\begin{array}{l}\text { Wilks' } \\
\text { Lambda }\end{array}$ & $\begin{array}{c}\mathrm{X}^{2} \text { for covariance } \\
\text { homogenity }\end{array}$ & $\begin{array}{c}\text { Can. } \\
\text { correlation }\end{array}$ & $\begin{array}{l}\% \text { corr. } \\
\text { classified }\end{array}$ \\
\hline \multirow{2}{*}{$\begin{array}{l}\text { Upper } \\
\text { canine }\end{array}$} & $\mathrm{M}$ & \multirow[t]{2}{*}{0.556} & \multirow[t]{2}{*}{49.27} & \multirow[t]{2}{*}{0.666} & 73.6 \\
\hline & $F$ & & & & 88.2 \\
\hline \multirow{2}{*}{$\begin{array}{l}\text { Lower } \\
\text { canine }\end{array}$} & $\mathrm{M}$ & \multirow[t]{2}{*}{0.603} & \multirow[t]{2}{*}{40.47} & \multirow[t]{2}{*}{0.630} & 82.7 \\
\hline & $\mathrm{F}$ & & & & 80.6 \\
\hline \multirow{2}{*}{$\begin{array}{l}\text { Upper } \\
\text { M2 }\end{array}$} & $\mathrm{M}$ & \multirow[t]{2}{*}{0.775} & \multirow[t]{2}{*}{25.49} & \multirow[t]{2}{*}{0.474} & 69.8 \\
\hline & $\bar{F}$ & & & & 80.0 \\
\hline \multirow{2}{*}{$\begin{array}{l}\text { Upper } \\
\text { M1 }\end{array}$} & $\mathrm{M}$ & \multirow[t]{2}{*}{0.792} & \multirow[t]{2}{*}{16.29} & \multirow[t]{2}{*}{0.456} & 70.7 \\
\hline & $\mathrm{F}$ & & & & 68.8 \\
\hline \multirow{2}{*}{$\begin{array}{l}\text { Lower } \\
\text { M2 }\end{array}$} & $\mathrm{M}$ & \multirow[t]{2}{*}{0.791} & \multirow[t]{2}{*}{17.31} & \multirow[t]{2}{*}{0.457} & 68.9 \\
\hline & $F$ & & & & 68.8 \\
\hline
\end{tabular}

The crown module for upper molars stays between the range of 10.210.49 , they can therefore beheld as mesodontic, the latter is distinctive to the present day Northern-Caucasoids [25]. Southern-Europeans have the smallest teeth or are microdontic in the present day, most macrodontic are equatorial groups, native Americans and arctic Mongoloids $[13,25]$. Between these two groups, most of the Asian groups, subSaharan Africans but also Northern-Europeans are positioned mesodonts $[13,25]$.

Most varied teeth are usually the third molars $[18,21]$. The same is also true for the group examined by us. Mandible sizes were more variable than maxilla sizes.

Subjects from the Estonian Iron Age have all quite similar sized teeth compared to skeletal series from neighbouring areas. All the teeth are smaller only in the first millennium Lithuanian comprehensive series. Figure 1 shows the robust indexes of teeth from the upper jaw which represent the overall size of the teeth from the neighbouring skeletal series. Size relations on the lower jaw are rather similar. 


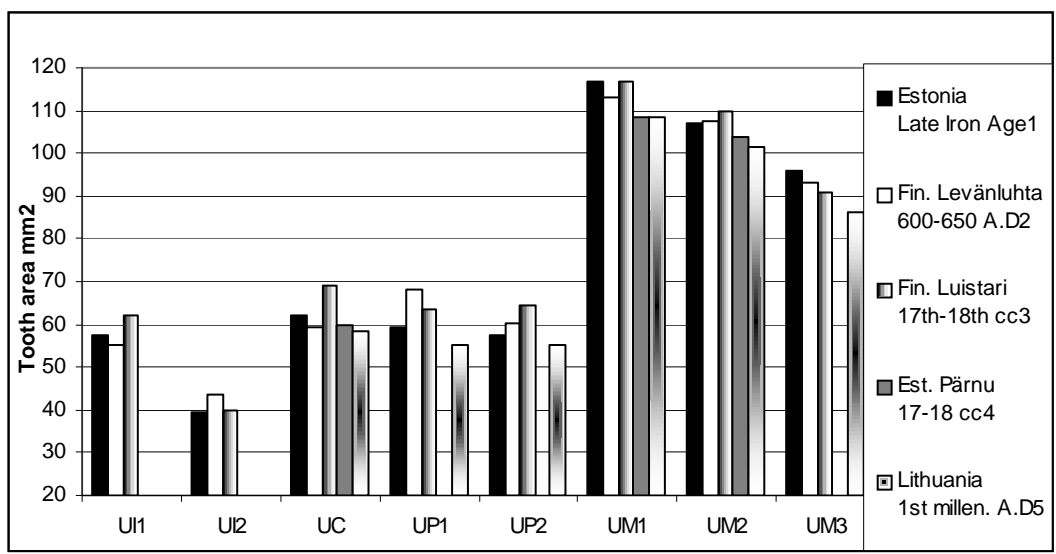

Figure 1. Tooth sizes (tooth area - BLxMD $\mathrm{mm}^{2}$ ) in the upper jaw in different skeleton series compared to the End of the Estonian Iron Age (2 Formisto 1993, 3 - Salo 2005, 4 - Allmäe, Limbo 2008, Papreckiene, Cesnys 1983).

The size of the teeth has been in continuous reduction since Pleistocene $[3,11,13,15,25]$. The cause for this has been a natural selection. The smaller teeth indicate the adaptation with the decreased energy demand and with smaller jaws and the smaller body size [15]. It is also thought that the increased population density causes teeth reduction [13]. The Probable Mutation Effect proposed by Brace and colleagues suggests that the development of sophisticated food preparation techniques and pottery removed the selective pressure being in favour of larger teeth and as the size became selectively insignificant, it allowed the reduction through the accumulated effect of random mutations [8, 13, 14]. Therefore the populations with a longer tradition of food preparation should show larger reduction in the teeth size [13]. The latter have been considered to be the cause why the east and the west of Eurasia have smaller teeth sizes compared to the rest of the world [13]. While the socalled meat eating populations have preserved larger teeth [24], the teeth sizes of early modern skeletal series from Pärnu, the town from Estonia, show negative secular changes in teeth sizes, both for men and women from the town of $16^{\text {th }}-17^{\text {th }}$ centuries, had smaller teeth than in the End of the Iron Age [2]. 
At the same time it is noted that the teeth sizes remaining the same [5] or even increase [15] in same areas over the time. Temporal increase in the tooth size is possibly reflecting improvements in the nutritional status [15]. The teeth size increase has been noticed in Europe after the Middle-Age in the regions with substantial nutrition changes [11]. But in addition to that, environmental factors have caused the teeth size increase. It has also been assumed that changes in the genetic constitution played its role [8].

The men's teeth are larger than the women's almost in all the human populations. The tooth size dimorphism differs from population to population, both in the percentage of dimorphism and in dimorphism patterning [12]. It has been noticed that some present day human populations have few dental dimensions statistically significantly lager in women than in men [4].

Humans have reduction not only in the teeth overall sizes but also the reduction of sexual dimorphism starting from Pleistocene, the greatest dimorphism staying in canines dimensions like in other primates [11]. Sexual dimorphism extends $3-9 \%$ in the canine size for modern day humans [15], it is especially larger for the upper canine BL sizes. BL sizes tend to be more affected by dimorphism than MD dimensions altogether [1]. The least difference can be seen in the dimensions of incisores of men and women. The same applies to the Estonian skeletal series form the End of the Iron Age.

The discriminate analysis is the most frequently used method for the determination of the subjects' sex by teeth dimensions. The correct classification has been made in over $90 \%$ of cases with the determination by different teeth dimensions [5, 15, 18]. The results of the analysis are population specific and tooth dimensions and discriminant formulas that are applicable in one population can not be used in others. The dimensions of canines [5, 17, 24], especially BL dimensions [1], are most preferable data for the discriminant analysis. Although the best results for the studied series were not achieved by using only the BL dimensions of canines but the BL and the MD dimensions of the upper canines (Table 2). 


\section{ACKNOWLEDGEMENT}

The study was undertaken in the framework of the target funded project of the Estonian Government (SF0130012s08).

\section{References}

1. Acharya A.B., Mainali S. (2008) Sex Discrimination Potential of Buccolingual and Mesiodistal Tooth Dimensions. J. Forensic Sci, 53, 3, 790-792.

2. Allmäe R., Limbo J. (2008) Pärnu garnisoni kalmistule maetute antropoloogiast. Pärnumaa 1. kd. Loodus. Aeg. Inimene. Eesti Entsüklopeediakirjastus. Tallinn. 369-387.

3. Alexandersen, V. (2003) Dental variation and change trough time in Nordic populations. In: A tooth for a tooth, Seminar for odontologists, osteologists and archaeologists. (Ed.) Iregren E. and Larsson L., Lund. 9-35.

4. Astete J. C., San Pedro V. J., Suazo G. I. (2009) Sexual Dimorphism in the Tooth Dimensions of Spanish and Chilean peoples. Int. J. Odontostomat, 3, 1, 47-50.

5. Balčiùnieně I, Jankauskas R (1993) Odontometry of Lithuanian Paleopopulations. Anthrop. Anz, 51, 31-39.

6. Brook A. H., Griffin R. C., Townsend G., Levisianos Y., Russell J., Smith R. N. (2009) Variability and patterning in permanent tooth size of four human ethnic groups. Archives of Oral Biology, 54s, s79-s85.

7. Brothwell D. R. (1982) Diggging up bones. London.

8. Calcagno J. M. (1989) Mechanisms of human dental reduction. A Case study of Post-Pleistocene Nubia. University of Kansas Publications in Anthropology 18, Lawrence: University of Kansas.

9. Dempsey P. J., Townsend G. C. (2001) Genetic and environmental contributions to variation in human tooth size. Heredity, 86, 685-693.

10. Formisto T. (1993) An Osteological Analysis of Human and Animal Bones from Leväluhta. Vammala Kirjapaino.

11. Frayer D.W. (1978) Evolution of Dentition in Upper Paleolithic and Mesolithic Europe. University of Kansas Publications in Antropology 18, Lawrence: University of Kansas.

12. Garn S. M.., Lewis A. B. (1967) Genetic Control of Sexual Dimorphism in Tooth Size. J. Dent. Reseach, 46, 963-972.

13. Hanihara T., Ishida H. (2005) Metric Dental Variation of Major Human Populations. Am. J. Physic. Anthrop, 128, 287-298. 
14. Hillson S. (1996) Dental anthropology. Cambridge University Press.

15. Kieser J. A. (2008) Human Adult Odontometrics. Cambridge Studies in Biological Anthropology 4. Cambridge University Press.

16. Kieser J. A., Gröneveld H. T. (1988) Fluctuating Odontometric Asymmetry in an Urban South African Black Population. J. Dent. Res, $67,9,1200-1205$.

17. Limbo J. (2001) Hambamõõtude soolised erinevused Pada kalmes. Eesti Antropoloogiaregistri Aastaraamat 2001. Tartu Ülikooli kirjastus, Tartu. 116-124.

18. Limbo J. (2003) Pada kalme (XI -XIII saj.) odontoloogiline iseloomustus. Odontology and Odontometry of Pada Cemetery $\left(11^{\text {th }}-13^{\text {th }} \mathrm{cc}.\right)$. Magister Thesis. Tartu. Library of Tartu University.

19. Matsumura H. (2001) Differentials of Yayoi immigration to Japan as derived from dental metrics. HOMO 52, 2, 135-156.

20. Parpeckienè I., Česnys G. (1981) Odontology of the $14^{\text {th }}-17^{\text {th }}$ century Lithuanians. Przeglad Antropologiczny, 47, 50-61.

21. Parpeckienè I., Česnys G. (1983) The teeth of the $1^{\text {st }}$ millenium A.D. population in Lithuania. Antropologie XXI/3, 243-250.

22. Palubeckaite Ž., Jankauskas R. (2001) Fluctuating asymmetry in two Lithuanian and Danish medieval and early modern samples Papers on Anthropology X, 207-221.

23. Recommendations 1980 Workshop of European anthropologistst, "Recommendations for Age and Sex Diagnoses of Skeletons." Journal of Human Evolution, 9, 517-549.

24. Salo K. (2005) What Ancient Human Teeth Can Reveal? Demography, Health, Nutrition and Biological Relations in Luistari. Master thesis. University of Helsinki.

25. Зубов А. А. 1968 Одонтология. Методика антропологических исследований. Изд. Наука. Москва.

\section{Address for correspondence:}

Jana Limbo

Tallinn University, Institute of History

Department of Archaeobiology and Ancient Technology

Rüütli 6, EE10130, Tallinn, Estonia

E-mail: jana.limbo@ai.ee 